\title{
Identifying Community/Public Health Nursing Competencies in Indonesia: A Modified Delphi Method
}

\author{
Destia Widyarani ${ }^{1,4}$, Tantut Susanto ${ }^{2}$, Dwi Wahyuni ${ }^{3}$, Huong Thi Thu Pham ${ }^{5}$ \\ ${ }^{1}$ Student of Master of Public Health Science, Universitas Jember, Jember, Indonesia \\ ${ }^{2}$ Department of Community, Family and Geriatric Nursing, Faculty of Nursing Universitas Jember, \\ Jember, Indonesia \\ ${ }^{3}$ Department of Biology, Faculty of Teaching and Education Science, Universitas Jember, Indonesia \\ ${ }^{4}$ Lecturer of Nursing Academy, Universitas Bondowoso, Bondowoso, Indonesia \\ ${ }^{5}$ Adult Nursing Department, Nursing Faculty, Haiphong University of Medicine and Pharmacy, \\ Haipong, Viet Nam \\ Corresponding Author: Tantut Susanto (tantut_s.psik@unej.ac.id)
}

Received: 9 April 2020

Revised: 21 August 2020

Accepted: 26 August 2020

\begin{abstract}
Background: Nurses in public health centers, or known as public health nurses (PHNs), have duties in implementing promotive, preventive, curative, and rehabilitative efforts. In Indonesia, there is no basic reference to the competencies that should be performed by PHNs. The provision of health services in the community should cover two areas, namely inside and outside the building (Minister of Health's Regulation No. 279 Year 2006); it causes nurses in the community to further hone their skills while in the field.

Purpose: This study aimed to identify the competencies of the Indonesian PHNs from experts using the C/PHN competencies of the Quad Council Coalition through a Delphi method.

Methods: This study was quantitative research with a Delphi method. We employed a purposive sampling technique to recruit the experts of public health nurses. The experts did a Delphi method to identify, analyze, and modify the C/PHN Competencies of the Quad Council Coalition into the Indonesian version of C/PHN Competencies with local cultures.

Results: Results showed that from eight domains of the Quad Council Coalition C/PHN competencies, there were changes for priority of the PHN competencies in Indonesia. All priorities were classified into eight groups, namely: (1) Leadership Skills and Thinking Systems; (2) Community Dimensions of Practice; (3) Assessment Analytic; (4) Policy Development and Program Planning; (5) Communication Skills; (6) Financial Planning and Management and Planning; (7) Public Health Sciences Skills; and (8) Cultural Competency.

Conclusion: The Quad Council Coalition of C/PHN competencies are appropriate with the Indonesian PHN competencies, although the priority is changed related to local wisdom as stated in the Minister of Health's Regulation No. 279 Year 2006. Therefore, the Indonesian $\mathrm{P} / \mathrm{HN}$ competencies should be developed to support the Indonesian health people through family approach.
\end{abstract}

Keywords: Community nurse; C/PHN; Delphi method; nurse competencies; public health 
How to Cite: Widyarani, D., Susanto, T., Wahyuni, D., \& Pham, H. T. T. (2020). Identifying community/public health nursing competencies in Indonesia: A modified Delphi method. Nurse Media Journal of Nursing, 10(3), 350-360. doi:10.14710/nmjn.v10i3.29435

Permalink/DOI: https://doi.org/10.14710/nmjn.v10i3.29435

\section{BACKGROUND}

Public health nurses (PHNs) are nurses who work with two main types of services, namely inside and outside the building (Swider, Krothe, Reyes, \& Cravetz, 2013). The data and information centre of the Indonesian Ministry of Health in 2017 showed that the number of PHNs was less than that of nurses working in hospitals, with a percentage of $29.46 \%$ (Ministry of Health Republic of Indonesia, 2018). This number is not equal with the amount of nurses' work in the community. Competencies are one aspect that should be owned by nurses faithfully in the community. With a small number of PHNs but a lot of work to do, it is likely that there are potential problems in achieving the programs in the community, one of which is Perkesmas (public health nursing [PHN] services). A study showed that the achievement of a public health program that was still not optimal was due to the inadequacy of the scope of the program with the completion of the social security program, which was strongly influenced by nurses' competencies in the community (Susanto, Bachtiar, \& Turwantoko, 2019).

The Ministry of Health of Republic Indonesia made a regulation on PHNs' duties for PHN services to achieve healthy programs in public health centres (Ministry of Health Republic of Indonesia, 2006). Previous studies indicated a relationship between PHNs' knowledge and attitudes and the performance of the PHN services (Septiyani, 2012) that resulted in low coverage of the implementation of PHN services (Susanto et al., 2019). Furthermore, PHN in Indonesia has only focused on indicators of program achievements without looking at the extent to which the process of PHN activities in the field is related to the role of PHNs based on the indicators of inputs, processes, and outputs of PHN activities (Susanto et al., 2019). This situation needs a solution for developing of PHNs' competencies for PHN services to achieve healthy programs in public health centres (Ministry of Health Republic of Indonesia, 2006).

The absence of a national reference competencies of PHNs and the lack of strict rules related to the development of PHN careers is a problem that should be solved. C/PHN Competencies of the Quad Council Coalition mentions the competencies needed by PHNs to analyse health problems in the community to conduct an evaluation. Expected competencies include skills in analysing public health assessments, planning public health programs, communication, understanding community culture, working with communities and stakeholders, as well as skills in using public health sciences, financial management, leadership, and systematic thinking (Quad Council Coalition of Public Health Nursing Organization, 2018).

\section{PURPOSE}

This study aimed to identify the competencies of the Indonesian PHNs based on the C/PHN competencies of the Quad Council Coalition through a Delphi method. 


\section{METHODS}

\section{Design and samples}

This research was a quantitative study with a Delphi method. We employed a purposive sampling technique to recruit the PHN experts. In this study, the experts did a Delphi method to identify, analyze, and modify the C/PHN Competencies of Quad Council Coalition into the Indonesian version of C/PHN Competencies with local cultures. The experts were people with expertise of public health nursing and hold a master degree in nursing. The experts were also active in Tridharma Perguruan Tinggi (threefold missions of higher education) consisting of (1) education in nursing, (2) research which is to carry out new discoveries in nursing science, and (3) community service which is to carry out the service to the community in maintaining the process of improving the welfare and health. Eight experts from three universities in two districts (Bondowoso and Jember) were involved in this study. In these universities, there are nursing study programs that actively carry out programs of public health nursing.

\section{Research instrument and data collection}

The C/PHN of the Quad Council Coalition is a measuring tool that was analyzed by each expert. This measurement tool is used to measure the level of competence of public health nursing and was developed by the Quad Council Coalition. There are 8 domains and 44 items which cover the competencies of public health nursing. Until now, Indonesia does not yet have a measurement tool used to measure the level of competence of public health nursing. The only reference used to guide public health nursing in public health centers in Indonesia is the Minister of Health's Regulation No. 279 Year 2006 about Perkesmas. However, this regulation does not explain in details about the competencies that public health nurses should have; it only describes two parts of the PHNs' activities: inside and outside the building.

\section{Data analysis}

The research consisted of three rounds (Figure 1). In the first round, each expert was given the C/PHN Competencies of the Quad Council Coalition and the Minister of Health's Regulation No. 279 Year 2006 about Perkesmas to be examined and analyzed. The experts were requested to evaluate the competencies using Likert scales of 1 to 4 for each competency item in the C/PHN Competencies: 1=not relevant, 2=quite relevant, $3=$ relevant, and $4=$ very relevant.

In the second round, the experts were invited to gather to do FGDs (focus group discussion) in one place. In this round, the experts were asked their respective opinions for each competency item in the C/PHN Competencies. The experts were asked for their opinions on each item whether it is in accordance with local cultures in Bondowoso and Jember. Then each expert made a rating for each item as in the first round.

In the third round, all experts were given the results of the study in the first round and the second round. They were also confirmed for approval for each item whether it could be used to test the draft of public health nursing competencies. In this final stage, the experts were requested to sign the agreement for the approved competencies. 


\section{Ethical consideration}

The ethical approval of this study was obtained from the Research Ethics Committee of the Faculty of Dentistry, Universitas Jember. All participants were informed of the study's purposes and procedures and signed informed consent for their participation.

\section{THE DELPHI METHOD}

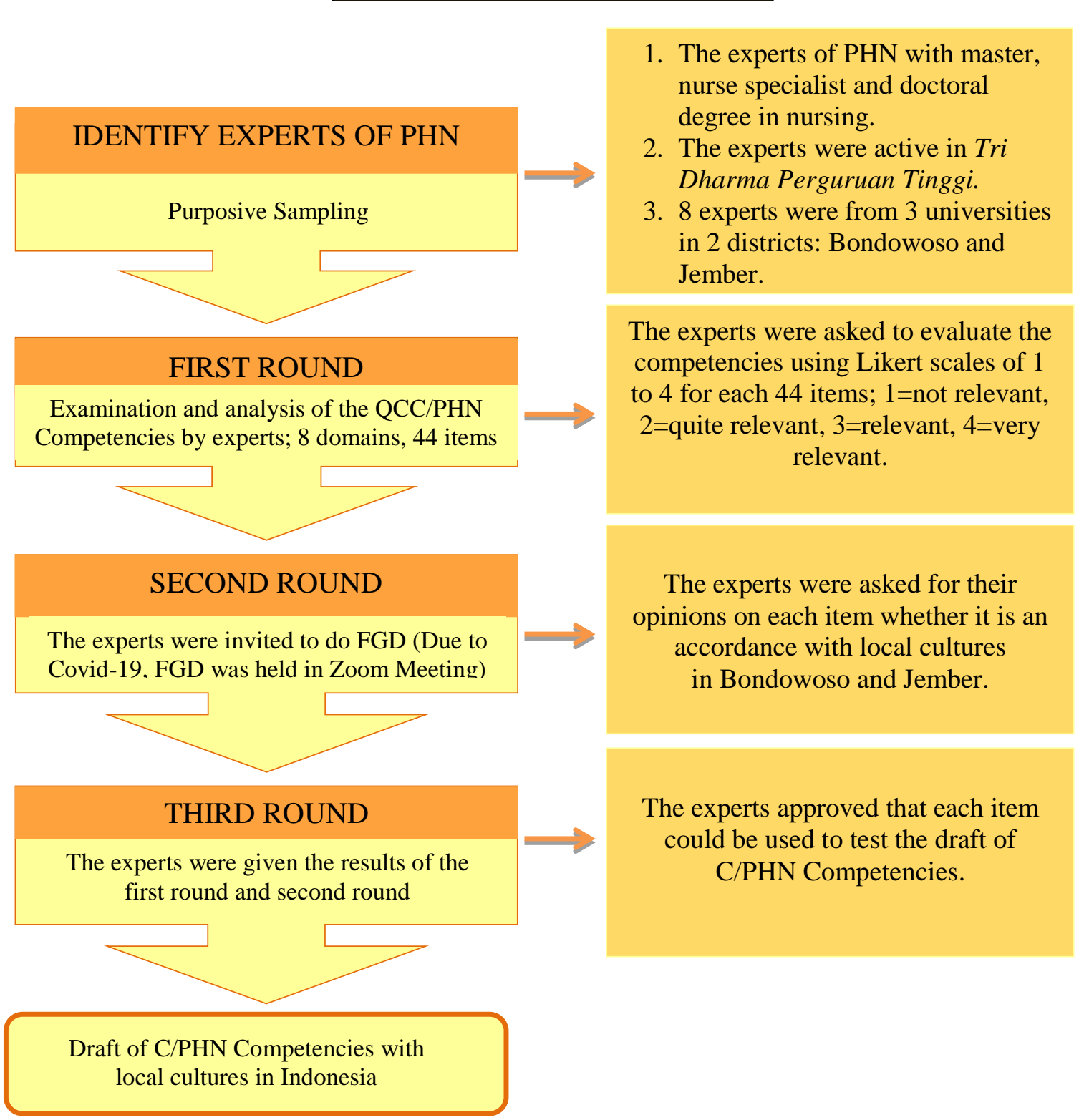

Figure 1. Diagram of the Delphi method

\section{RESULTS}

Eight experts of public health nursing selected based on the inclusion criteria of the study participated in the study. These participants came from three universities in the area of Bondowoso and Jember, Indonesia. The characteristics of eight experts of PHN are presented in Table 1. 
Table 1. Characteristic of experts of PHN in this study $(n=8)$

\begin{tabular}{lll}
\hline \multicolumn{1}{c}{ Characteristics } & $f$ & $\%$ \\
\hline Age & & \\
$20 \mathrm{~s}$ & 1 & 12.50 \\
$30 \mathrm{~s}$ & 3 & 37.50 \\
$40 \mathrm{~s}$ & 4 & 50.00 \\
Gender & & \\
$\quad$ Male & 2 & 25.00 \\
$\quad$ Female & 6 & 75.00 \\
Education & 5 & \\
$\quad$ Master degree & 5 & 62.50 \\
$\quad$ Nurse specialist & 2 & 25.00 \\
$\quad$ Doctoral degree & 1 & 12.50 \\
Experience of training & & \\
$\quad$ Yes & 4 & 50.00 \\
No & 4 & 50.00 \\
\hline
\end{tabular}

Table 1 shows that most community nursing experts in this study were aged in the span of the 40s (50\%) and females (75\%). Most experts hold master degree education $(62.5 \%)$. A half of the experts $(50 \%)$ already attended Perkesmas training. Although not all experts had participated in Perkesmas training, they are experts in the field of the public health nursing, education, profession, and research.

In round I, the experts as participants were asked to analyze and examine the 44 items in QCC which are divided into eight domains by using Likert scales and compared it with the existing legislation (the Minister of Health's Regulation No. 279 Year 2006 about Perkesmas). Then, the result was analyzed based on the mean value of each item.

In round II, eight nursing experts gathered in a place to give the assessment results that had been done before. In this discussion, group forum of experts was requested to assess the items and determine whether words or sentences in the items should be changed according to local wisdom. Once the data were collected, each expert determined to carry out a validity test for each item (Waltz, Strickland \& Lenz, 2010). The validity and the reliability test of this instrument was conducted on eight public health nursing experts in February 2020. Table 2 shows the results of round I and II of the study.

Table 2. Competency items by highest rating

\begin{tabular}{|c|c|c|c|c|}
\hline Domain & Rank & $\mathrm{C} / \mathrm{PHN}$ & Delphi Results & Mean \pm SD \\
\hline \multirow[t]{4}{*}{$\begin{array}{l}\text { I. Analytic } \\
\text { Skills }\end{array}$} & $1^{\mathrm{st}}$ & $1 \mathrm{~A} 8$ & $\begin{array}{l}\text { Implement ethical, legal, and policy } \\
\text { guidelines, and principles for maintaining, } \\
\text { using, and disseminating data and } \\
\text { information }\end{array}$ & $3.75 \pm 0.46$ \\
\hline & $2^{\text {nd }}$ & $1 \mathrm{~A} 5$ & To interpret valid and appropriate data & $3.63 \pm 0.52$ \\
\hline & $3^{\text {rd }}$ & $1 \mathrm{~A} 11$ & $\begin{array}{l}\text { Using practice results from various fields of } \\
\text { science }\end{array}$ & $3.13 \pm 0.35$ \\
\hline & $4^{\text {th }}$ & 1A7 & $\begin{array}{l}\text { Contributing to public health assessments } \\
\text { using subjective and objective data }\end{array}$ & $2.88 \pm 1.13$ \\
\hline
\end{tabular}


Table 2. (Continued)

\begin{tabular}{|c|c|c|c|c|}
\hline Domain & Rank & $\mathrm{C} / \mathrm{PHN}$ & Delphi Results & Mean \pm SD \\
\hline \multirow[t]{2}{*}{$\begin{array}{l}\text { I. Analytic } \\
\text { Skills }\end{array}$} & $5^{\text {th }}$ & 1A1 & $\begin{array}{l}\text { Assess health status using multiple data } \\
\text { sources }\end{array}$ & $2.75 \pm 1.04$ \\
\hline & $6^{\text {th }}$ & $1 \mathrm{~A} 2 \mathrm{a}$ & $\begin{array}{l}\text { Using ecological and epidemiological } \\
\text { perspectives }\end{array}$ & $2.75 \pm 1.04$ \\
\hline II. Policy & $1^{\text {st }}$ & $2 \mathrm{~A} 7$ & Organizational plan development & $3.88 \pm 0.35$ \\
\hline \multirow[t]{5}{*}{$\begin{array}{l}\text { Development } \\
\text { and Program } \\
\text { Planning Skills }\end{array}$} & $2^{\text {nd }}$ & 2A9 & $\begin{array}{l}\text { Using program planning skills and CBPR } \\
\text { (Community Based Participatory Research } \\
\text { (i.e., collaboration, reflection, capacity } \\
\text { building)) to implement strategies to } \\
\text { engage marginalized/ disadvantaged } \\
\text { population groups in making decision that } \\
\text { affect their health and well-being }\end{array}$ & $3.13 \pm 0.35$ \\
\hline & $3^{\text {rd }}$ & $2 \mathrm{~A} 2$ & $\begin{array}{l}\text { Explaining the implications of the } \\
\text { potential impact of public health policy } \\
\text { programs }\end{array}$ & $3.00 \pm 0.93$ \\
\hline & $4^{\text {th }}$ & 2A5 & Using decision-making methods & $3.00 \pm 0.93$ \\
\hline & $5^{\text {th }}$ & $2 \mathrm{~A} 6 \mathrm{~b}$ & $\begin{array}{l}\text { Planning a consistent public health care } \\
\text { service }\end{array}$ & $3.00 \pm 0.93$ \\
\hline & $6^{\text {th }}$ & $2 \mathrm{~A} 8$ & $\begin{array}{l}\text { Adherent to organizational procedures and } \\
\text { policies }\end{array}$ & $2.75 \pm 1.04$ \\
\hline \multirow{6}{*}{$\begin{array}{l}\text { III. } \\
\text { Communication } \\
\text { Skills }\end{array}$} & $1^{\text {st }}$ & 3A6 & $\begin{array}{l}\text { Using communication model in } \\
\text { communication }\end{array}$ & $3.75 \pm 0.46$ \\
\hline & $2^{\text {nd }}$ & $3 \mathrm{~A} 4$ & $\begin{array}{l}\text { Using various methods in spreading } \\
\text { general health information }\end{array}$ & $3.00 \pm 0.93$ \\
\hline & $3^{\text {rd }}$ & $3 \mathrm{~A} 2 \mathrm{~b}$ & $\begin{array}{l}\text { Use input from individuals, families and } \\
\text { groups }\end{array}$ & $2.88 \pm 1.13$ \\
\hline & $4^{\text {th }}$ & $\begin{array}{l}3 \mathrm{~A} 5 \mathrm{a} \\
\& \mathrm{~b}\end{array}$ & Presenting health information & $2.88 \pm 1.13$ \\
\hline & $5^{\text {th }}$ & $3 \mathrm{~A} 2 \mathrm{a}$ & $\begin{array}{l}\text { Applying critical thinking and cultural } \\
\text { conscious }\end{array}$ & $2.75 \pm 1.04$ \\
\hline & $6^{\text {th }}$ & $3 \mathrm{~A} 1$ & $\begin{array}{l}\text { Determining health, awareness, and } \\
\text { health-conscious }\end{array}$ & $2.63 \pm 0.92$ \\
\hline \multirow{3}{*}{$\begin{array}{l}\text { IV. } \\
\text { Competency } \\
\text { Skills }\end{array}$} & $1^{\text {st }}$ & $4 \mathrm{~A} 5$ & $\begin{array}{l}\text { Using cultural models based on research } \\
\text { results in a working environment }\end{array}$ & $3.00 \pm 0.93$ \\
\hline & $2^{\text {nd }}$ & $4 \mathrm{~A} 3$ & $\begin{array}{l}\text { To provide a responsive public health care } \\
\text { service using cultural aspects }\end{array}$ & $2.88 \pm 1.13$ \\
\hline & $3^{\text {rd }}$ & $4 \mathrm{~A} 1$ & $\begin{array}{l}\text { Determining effective health in } \\
\text { cooperation }\end{array}$ & $2.63 \pm 0.92$ \\
\hline \multirow{5}{*}{$\begin{array}{l}\text { V. Community } \\
\text { Dimensions of } \\
\text { Practice Skills }\end{array}$} & $1^{\text {st }}$ & $5 \mathrm{~A} 3 \mathrm{a}$ & $\begin{array}{l}\text { Choosing the stakeholders needed to } \\
\text { address public health issues }\end{array}$ & $3.75 \pm 0.46$ \\
\hline & $2^{\text {nd }}$ & $5 \mathrm{~A} 6$ & Use input from multiple sources & $3.75 \pm 0.46$ \\
\hline & $3^{\text {rd }}$ & 5A5 & Using Community assets and resources & $3.13 \pm 0.35$ \\
\hline & $4^{\text {th }}$ & $5 \mathrm{~A} 8$ & $\begin{array}{l}\text { Identifying evidence of the effectiveness } \\
\text { of community engagement strategies }\end{array}$ & $3.00 \pm 0.93$ \\
\hline & $5^{\text {th }}$ & $5 \mathrm{~A} 2$ & Developing formal and informal networks & $2.88 \pm 1.13$ \\
\hline
\end{tabular}


Table 2. (Continued)

\begin{tabular}{|c|c|c|c|c|}
\hline Domain & Rank & $\mathrm{C} / \mathrm{PHN}$ & Delphi Results & Mean \pm SD \\
\hline $\begin{array}{l}\text { VI. Public } \\
\text { Health Sciences }\end{array}$ & $1^{\text {st }}$ & $6 \mathrm{A5}$ & $\begin{array}{l}\text { Using various sources and methods to } \\
\text { access public health information }\end{array}$ & $3.88 \pm 0.35$ \\
\hline \multirow[t]{5}{*}{ Skills } & $2^{\text {nd }}$ & $6 \mathrm{~A} 1$ & $\begin{array}{l}\text { Using health determinants and research- } \\
\text { based practices }\end{array}$ & $2.75 \pm 1.04$ \\
\hline & $3^{\text {rd }}$ & 6А6a & $\begin{array}{l}\text { Utilizing research results to inform public } \\
\text { health nursing practices }\end{array}$ & $2.75 \pm 1.04$ \\
\hline & $4^{\text {th }}$ & $6 \mathrm{~A} 7$ & $\begin{array}{l}\text { Complying with all aspects of client } \\
\text { confidentiality and protection }\end{array}$ & $2.75 \pm 1.04$ \\
\hline & $5^{\text {th }}$ & $6 \mathrm{~A} 2 \mathrm{~b}$ & $\begin{array}{l}\text { Assess hazards and reduce risk of } \\
\text { exposure and injuries in natural and } \\
\text { artificial environments }\end{array}$ & $2.63 \pm 1.06$ \\
\hline & $6^{\text {th }}$ & $6 \mathrm{~A} 3$ & $\begin{array}{l}\text { Using research-based practices in the } \\
\text { program ( } 12 \text { indicators of PIS PK) }\end{array}$ & $2.63 \pm 0.92$ \\
\hline \multirow{6}{*}{$\begin{array}{l}\text { VII. Financial } \\
\text { Planning and } \\
\text { Management } \\
\text { and Planning } \\
\text { Skills }\end{array}$} & $1^{\mathrm{st}}$ & 7A6 & $\begin{array}{l}\text { Explain the priority implications of } \\
\text { organizational financing }\end{array}$ & $3.13 \pm 0.35$ \\
\hline & $2^{\text {nd }}$ & 7A7 & $\begin{array}{l}\text { Explaining public health care services and } \\
\text { programmatic needs to inform budget } \\
\text { priorities }\end{array}$ & $3.13 \pm 0.35$ \\
\hline & $3^{\text {rd }}$ & 7A11 & $\begin{array}{l}\text { Using information systems and public } \\
\text { health communication }\end{array}$ & $3.13 \pm 0.35$ \\
\hline & $4^{\text {th }}$ & 7A2 & $\begin{array}{l}\text { Explaining the role of public health nurses } \\
\text { in emergency preparedness and disaster } \\
\text { response }\end{array}$ & $2.88 \pm 1.13$ \\
\hline & $5^{\text {th }}$ & 7A5 & $\begin{array}{l}\text { To interpret the impact of financing } \\
\text { limitations in service delivery }\end{array}$ & $2.63 \pm 0.92$ \\
\hline & $6^{\text {th }}$ & 7A8a & Identifying data to evaluate services & $2.63 \pm 0.92$ \\
\hline \multirow{6}{*}{$\begin{array}{l}\text { VIII. } \\
\text { Leadership } \\
\text { Skills and } \\
\text { Thinking } \\
\text { Systems }\end{array}$} & $1^{\text {st }}$ & $8 \mathrm{~A} 2$ & Implementing a thinking system & $3.88 \pm 0.35$ \\
\hline & $2^{\text {nd }}$ & $8 \mathrm{~A} 6$ & $\begin{array}{l}\text { Committed to lifelong learning, } \\
\text { professional development, and advocacy }\end{array}$ & $3.88 \pm 0.35$ \\
\hline & $3^{\text {rd }}$ & $8 \mathrm{~A} 8$ & $\begin{array}{l}\text { Facilitating the development of working } \\
\text { groups }\end{array}$ & $3.75 \pm 0.46$ \\
\hline & $4^{\text {th }}$ & $8 \mathrm{~A} 1$ & $\begin{array}{l}\text { Demonstrate the ethical standards of } \\
\text { practice in all aspects }\end{array}$ & $3.00 \pm 0.93$ \\
\hline & $5^{\text {th }}$ & $8 \mathrm{~A} 3$ & Participating in stakeholder meetings & $2.75 \pm 1.04$ \\
\hline & $6^{\text {th }}$ & $8 \mathrm{~A} 4 \mathrm{a}$ & Identifying internal and external factors & $2.63 \pm 0.92$ \\
\hline
\end{tabular}

In round III, the experts approved the feasibility of instrument with 44 items by signing a letter. Additionally, the researchers also get the results of domain rankings from Delphi results by experts and presented these results in Table 3.

As shown in Table 3, the highest rated domain is Domain VIII: Leadership Skills and Thinking Systems, while the lowest one is Domain IV: Cultural Competency Skills. 
Table 3. Domains by highest rating

\begin{tabular}{clc}
\hline Rank & \multicolumn{1}{c}{ Domains } & Mean \pm SD \\
\hline $1^{\text {st }}$ & VIII. Leadership Skills and Thinking Systems & $3.32 \pm 0.59$ \\
$2^{\text {nd }}$ & V. Community Dimensions of Practice Skills & $3.30 \pm 0.42$ \\
$3^{\text {rd }}$ & I. Assessment Analytic Skills & $3.15 \pm 0.44$ \\
$4^{\text {th }}$ & II. Policy Development and Program Planning Skills & $3.13 \pm 0.39$ \\
$5^{\text {th }}$ & III. Communication Skills & $2.98 \pm 0.40$ \\
$6^{\text {th }}$ & VII. Financial Planning and Management and Planning Skills & $2.92 \pm 0.25$ \\
$7^{\text {th }}$ & VI. Public Health Sciences Skills & $2.90 \pm 0.48$ \\
$8^{\text {th }}$ & IV. Cultural Competency Skills & $2.84 \pm 0.19$ \\
\hline
\end{tabular}

\section{DISCUSSION}

In this study, we identified the competencies of Indonesian of PHN from experts using the C/PHN Competencies of the Quad Council Coalition through a Delphi method. From eight domains of the Quad Council Coalition C/PHN Competencies, there were changes for priority of PHN competencies in Indonesia. All priorities were classified into eight groups, namely: (1) Leadership Skills and Thinking Systems; (2) Community Dimensions of Practice Skills; (3) Assessment Analytic Skills (4) Policy Development and Program Planning Skills; (5) Communication Skills; (6) Financial Planning and Management and Planning Skills; (7) Public Health Sciences Skills; and (8) Cultural Competency Skills.

In this study, Domain VIII (Leadership Skills and Thinking Systems) in C/PHN Competencies of the Quad Council Coalition became the top rank after the Delphi and was followed by Domain V (Community Dimensions of Practice Skills). This is influenced by the implications in Indonesia. In fact, there is no basic reference to the competencies of public health nurses, it is distinguished by location of activities that are in the building and outside the building (Minister of Health's Regulation No. 279 Year 2006). It causes the nurses in the community to further hone their skills while in the field (Ministry of Health Republic Indonesia, 2006). According to the authors' observations, Domain VIII became first domain in the Indonesian version of C/PHN Competencies, according to experts, because the critical thinking ability of a nurse in primary health care is very important. Public health nurses are required to have good leadership skills because they are responsible for the success of the promotive and prevention program of a health problem in an area. In addition to being responsible for leading the community in efforts to improve health status, public health nurses must also have the ability to develop good interactions with cross-sectors. Therefore, this is related to the domain that is ranked second in the Indonesian version of C/PHN Competencies, i.e., Community Dimensions of Practice Skills. In Domain V, public health nurses have the ability to manage good relations between stakeholders, business owners, community leaders, religious leaders, and the community themselves in handling all health problems in an area.

Being third rank in the study was Domain I (Assessment Analytic Skills) of the C/PHN Competencies of the Quad Council Coalition, followed by the fourth rank was Domain II (Policy Development and Program Planning Skills). In Indonesia, there are no rules 
governing the competency of nurses in the community (Reckinger, Cross, Block, Josten, $\&$ Savik, 2013). The rules in Indonesia used by nurses in the community as a reference work contain only job description and targets for the achievement of the program (Ministry of Law and Human Rights Republic Indonesia, 2014). The rule of law used is Minister of Health's Regulation No. 279 Year 2006 (Ministry of Health Republic Indonesia, 2006) and the Minister of Health's Decree No. 908 Year 2010 (Ministry of Health Republic Indonesia, 2010). The third rank in the Indonesian version of C/PHN competencies according to experts was Domain I (Assessment Analytic Skills). Public health nursing experts agree that public health nurses must have good analytical skills. Community nurses must be able to analyse health problems obtained from a variety of data sources, including ecological perspectives, epidemiological data, and health risk findings from cross sectors in both qualitative and quantitative data. The experts agreed that Domain II (Policy Development and Program Planning Skills) was ranked fourth in the Indonesian version of the C/PHN Competencies domain because public health nurses have a very important role in introducing government programs in the health sector, even from the planning stage to ensuring compliance with policy, ethical code, and law.

The fifth place in this study was Domain III (Communication Skills) and as the sixth rank was Domain VII (Financial Planning and Management Skills and Planning). There are no laws or regulations governing the competency of nurses in the field of communication and finance that are destined for nursing personnel in primary service order. Some experts argue that good communication skills and financial management skills are both programs acquired by the community nurse in the work. It can be concluded that this ability can be improved from work experience; the longer the community nurse experience works, the better the ability of communication and financial management in the community will be. Different from the management and planning skills, although specifically nurses have a branch of nursing management (Cross et al., 2006; Hewitt, Roye, \& Gebbie, 2014; Polivka \& Chaudry, 2015), but the theory is more appropriate to use by nurses in clinical settings, not in the community. In the public order, in relation to primary service, nurse should carry out the rules and policies that are contained in the Minister of Health's Regulation No. 279 Year 2006 about Perkesmas (Ministry of Health Republic Indonesia, 2006) and the Minister of Health's Decree 908 Year 2010 about family care (Ministry of Health Republic Indonesia, 2010).

Domain VI (Public Health Sciences Skills) in the C/PHN Competencies of the Quad Council Coalition was ranked seventh in this study. The last rank was Domain IV (Competency Skills with Cultural Aspects). Some experts in the study agreed that the competencies that the nurses have in the community are heavily influenced by the nurses' work experiences. Longer working experience will make nurses increase their expertise in doing their job in the field. In addition, regional cultures also greatly affect the working style as well as the results of working nurses in the community (American Public Health Association, 2013). Clearly, there is no rule to set points on culture in the implementation of the program by the nurses in the community (Ministry of Law and Human Rights Republic Indonesia, 2014). 
The implication of this study is the development of the Indonesian version of the PHN competencies. There are no rules governing nurses' competencies in the community. The rules used by community nurses as a reference work contain only job description and targets for the achievement of the program (Kalb et al., 2006; Carter, Kaiser, O'Hare, \& Callister, 2006). The nurses in the community are to further hone their skills while in the field. There are no laws or regulations governing the nurses' competencies in the field of communication and finance that are destined for nursing personnel in primary service order. Community nurses' ability can develop from work experiences. The longer the experience, the better the ability of communication and financial management in the community will be. The nurses' competencies in the community are significantly influenced by the nurses' work experiences.

\section{CONCLUSION}

The Quad Council Coalition of C/PHN Competencies are appropriate with Indonesian $\mathrm{P} / \mathrm{HN}$ competencies, although the priority is changed that is related of local wisdom of Perkesmas as stated in Minister of Health's Regulation No. 279 Year 2006. Therefore, the Indonesian $\mathrm{P} / \mathrm{HN}$ competencies should be developed to support the Indonesian Health People through family approach.

\section{ACKNOWLEDGMENT}

The authors would like to thank the Ministry of Research and Technology / National Research and Innovation Agency (BRIN) for funding the study through the 2020 Thesis Grants.

\section{CONFLICT OF INTEREST}

The authors declare no conflict of interest.

\section{REFERENCES}

American Public Health Association. (2013). The definition and practice of public health nursing. Washington D.C.: American Public Health Association.

Carter, KF., Kaiser, KL., O'Hare, PA., \& Callister, LC. (2006). Use of PHN competencies and ACHNE essentials to develop teaching-learning strategies for generalist C/PHN curricula. Public Health Nursing, 23(2), 146-160. doi:10.1111/j.1525-1446.2006.230206.x

Cross, S., Block, D., Josten, L., Reckinger, D., Olson Keller, L., Strohschein, S., Savik, K. (2006). Development of the public health nursing competency instrument. Journal of Public Health Nursing, 23(2), 108-114. doi:10.1111/j.15251446.2006.230203.x

Hewitt, CM., Roye, C., \& Gebbie, KM. (2014). Core competency model for the family planning public health nurse. Journal of Public Health Nursing, 31(5), 472-479. doi: $10.1111 / \mathrm{phn} .12133$

Kalb, KB., Cherry, NM., Kauzloric, J., Brender, A., Green, K., Miyagawa, LA., \& Shinoda-Mettler, A. (2006). A competency-based approach to public health nursing performance appraisal. Journal of Public Health Nursing, 23(2), 115-138. doi: 10.1111/j.1525-1446.2006.230204.x 
Ministry of Health of Republic Indonesia. (2006). Perawatan kesehatan masyarakat (Perkesmas) No. SK/279/MENKES/IV/2006 [Public health nursing (PHN) no. SK/279/MENKES/IV/2006]. Jakarta: Kementerian Kesehatan.

Ministry of Health of Republic Indonesia. (2018). Data dan informasi. [Data and information]. Jakarta: Kementerian Kesehatan.

Ministry of Law and Human Rights of Republic Indonesia. (2014). Undang-undang Republik Indonesia nomor 38 tahun 2014 tentang keperawatan [The constitution of the Republic of Indonesian no. 38 year 2014 about nursing]. Jakarta: Kementerian Hukum dan HAM.

Ministry of Health of Republic Indonesia. (2006). Keputusan menteri kesehatan no. 279 tentang pedoman penyelengaraan upaya keperawatan kesehatan masyarakat di puskesmas. [The minister of health's decree no. 279 about the guidelines on the administration of public health nursing efforts in community health center]. Jakarta: Kementerian Kesehatan.

Ministry of Health of Republic Indonesia. (2010). Keputusan menteri kesehatan no. 908 tentang pedoman pelayanan keperawatan keluarga [The minister of health's decree no. 980 about the guidelines of nursing family service]. Jakarta: Kementerian Kesehatan.

Polivka, BJ., \& Chaudry, RV. (2015). Public health nursing position descriptions congruence with ANA standards, public health essential services, and Quad council domains. Journal of Public Health Nursing, 32(5), 532-542. doi: 10.1111/phn. 12148

Quad Council Coalition of Public Health Nursing Organization. (2018). Community/public health nursing competencies. North Carolina: Quad Council Coalition of Public Health Nursing Organizations.

Reckinger, D., Cross, S., Block, DE., Josten, L., \& Savik, K. (2013). Public Health nursing competency instrument: Scale reduction and reliability of factors. Journal of Public Health Nursing, 30(6), 566-574. doi: 10.1111/phn.12032

Septiyani, R. (2012). Analisis beberapa faktor individu, organisasi, psikologi yang berhubungan dengan kinerja koordinator program keperawatan kesehatan masyarakat (PERKESMAS) di puskesmas kota Semarang tahun 2012 [Analysis of several individual, organisational, and psychological factors relating to performance of coordinator program of public health nursing in community health centers in Semarang. Master Thesis: Universitas Diponegoro.

Susanto, T., Bachtiar, S., \& Turwantoko, T. (2019). Performance of public health nurses and coverage of the nursing care program by community health centers in Jember, Indonesia. International Journal Community Based Nursing and Midwifery, 7(2), 161-168. doi:10.30476/IJCBNM.2019.44887

Swider, S. M., Krothe, J., Reyes, D., \& Cravetz, M. (2013). The quad council practice competencies for public health nursing. Journal of Public Health Nursing, 30(6), 519-536. doi:10.1111/phn. 12090

Waltz, C., Strickland, O., \& Lenz, E. (2010). Measurement in nursing and health research: Fourth edition. New York: Springer Publishing Company. 